\title{
Desain Kapal 3-in-1 Multipurpose Container-Passenger- Vehicle dengan Variasi Bangunan Atas Portable sebagai Penunjang Tol Laut di Wilayah Indonesia Timur
}

\author{
Anindra Ahmad Farras dan Hesty Anita Kurniawati \\ Departemen Teknik Perkapalan, Fakultas Teknologi Kelautan, Institut Teknologi Sepuluh Nopember (ITS) \\ e-mail: tita@na.its.ac.id
}

\begin{abstract}
Abstrak-Sebagai penunjang untuk membantu penyebaran logistik di Indonesia, pemerintah membangun banyak kapal perintis yang tersebar di berbagai wilayah Indonesia. Salah satunya adalah kapal perintis yang memiliki muatan 3-in-1 yang mampu membawa tiga muatan berbeda secara langsung untuk meningkatkan pendapaan. Faktanya, kapal-kapal berpelayaran multiport memiliki kekurangan jika terjadi fluktuasi penumpang karena terdapat perbedaan kebutuhan di tiap daerah. Hal tersebut berpengaruh terhadap penurunan pendapatan karena terdapat ruangan yang tidak terisi. Oleh karena itu dibutuhkan kapal dengan modul bangunan atas portable agar dapat mengatur ruangan kapal sesuai yang dibutuhkan. Jika penumpang berkurang ruangan akan diganti oleh kontainer. Kapal tersebut beroperasi di wilayah timur Indonesia pada rute pelayaran Makassar-Bitung-Tertate-Ambon-Sorong-Jayapura untuk memfasilitasi ketersediaan barang di wilayah timur Indonesia. Dalam mendesain kapal dilakukan analisis teknis yang meliputi perhitungan ukuran utama, perhitungan stabilitas, perhitungan trim, dan perhitungan freeboard. Kapal yang didesain memiliki ukuran Panjang antar Garis Tegak (Lpp): 139,8 meter, lebar (B): 24 meter, Tinggi (H): 12,8 meter, dan Sarat (T): 5,95 meter dengan kecepatan: 18 knots. Dengan ukuran tersebut kapal memiliki dua pilihan bangunan atas pada kondisi pertama kapal dapat mengangkut 1400 penumpang, 41 TEUs kontainer, 40 unit mobil dengan panjang kurang dari 5 meter, 12 unit truk atau bus dengan panjang 7 meter sampai 10 meter, dan 322 unit sepeda motor. Sedangkan untuk kondisi kedua kapal dapat mengangkut 1400 penumpang, 41 TEUs kontainer, 40 unit mobil dengan panjang kurang dari 5 meter, 12 unit truk atau bus dengan panjang 7 meter sampai 10 meter, dan 322 unit sepeda motor.
\end{abstract}

Kata Kunci- Bangunan Atas Portable, Desain Kapal, Analisis Teknis, Kapal 3-in-1, Wilayah Timur Indonesia.

\section{PENDAHULUAN}

$\mathrm{I}_{\mathrm{p}}^{\mathrm{s}}$ NDONESIA adalah salah satu negara dengan tingkat perekonomian berkembang memiliki peran penting dalam perekonomian. Letak wilayah Indonesia yang diapit oleh dua samudera menjadikan Indonesia sebagai negara yang strategis untuk dilewati kapal-kapal dari Eropa menuju Asia Timur dan sebaliknya. Kondisi ini dimanfaatkan di era kepresidenan Joko Widodo. Peluang bidang maritim diangkat menjadi salah satu fokusan pengembangan di Indonesia dengan memaksimalkan potensi maritim yang ada di Indonesia. Tujuan untuk memfokuskan pengembangan potensi maritim adalah menjadikan Indonesia sebagai menjadi poros maritim dunia. Tidak hanya pengembangan kemaritiman Indonesia keluar, Indonesia sebagai poros maritim dunia juga direncanakan untuk pemanfaatan sumber daya alam di Indonesia. Program
Tol laut adalah salah satu program andalan untuk menjadikan Indonesia sebagai poros maritim dunia tersebut, dimana Tol Laut ini memiliki fungsi sebagai konektivitas pendistribusian logistik secara merata ke seluruh wilayah Indonesia dengan adanya kapal yang melayari secara rutin dan terjadwal dari barat sampai ke timur Indonesia.

Sebagai penunjang untuk membantu penyebaran logistik di Indonesia, pemerintah membangun banyak kapal perintis yang tersebar di berbagai wilayah Indonesia. Walaupun sudah ada kapal yang mampu meningkatkan keuntungan dengan cara mengangkut tiga muatan berbeda secara langsung, akan tetapi masih terdapat kekurangan jika jumlah penumpang berfluktuasi. Jumlah penumpang di kapal berpelayaran multiport pada umumnya memiliki jumlah penumpang yang berfluktuasi tergantung pada keadaan daerahnya sehingga ruangan-ruangan pada kapal pada waktu tertentu kosong dan tidak termanfaatkan. Hal tersebut dikarenakan pada wilayah tertentu sudah memiliki fasilitas transportasi alternatif seperti pesawat yang memiliki waktu perjalanan yang lebih cepat dibandingkan kapal laut akan tetapi di wilayah lainnya transportasi kapal masih lebih efektif dan efisien untuk berpergian. Dari masalah tersebut karena ruangan-ruangan yang disediakan untuk penumpang terkadang kosong dan tidak terpakai menyebabkan keuntungan perusahaan berkurang.

Dari masalah di atas, dibutuhkan kapal yang dapat beroperasi sesuai dengan ketersediaan penumpang. Sehingga ruangan-ruangan yang terdapat di kapal tidak kosong tidak mengalami penurunan keuntungan. Oleh sebab itu, pada penelitian ini ini akan dianalisis kapal 3-in-1 multipurpose dengan bangunan atas portable yang dapat menyesuaikan ruangan kapal sesuai dengan perubahan jumlah penumpang. Kapal tersebut direncanakan berlayar di wilayah Indonesia Timur pada pelabuhan-pelabuhan di bawah PELINDO IV. Penentuan wilayah tersebut didasari dari dibutuhkannya fasilitas untuk mendistribusikan barang-barang ke wilayah Indonesia Timur.

\section{II.TINJAUAN PUSTAKA}

\section{A. Tol Laut}

Tol Laut adalah konektivitas di perairan Indonesia yang efektif adanya kapal-kapal yang berlayar secara rutin dan terjadwal dari barat sampai ke timur Indonesia. Salah satu program untuk mendukung Indonesia sebagai poros maritim dunia 2045 ini berfokus dalam penggerak roda perekonomian 
secara merata di seluruh wilayah Indonesia. Dengan adanya konsep tersebut selain bisa meratakan pertumbuhan ekonomi di seluruh wilayah Indonesia, pergerakan kapal dagang internasional di wilayah dalam Indonesia dapat diminimalisir dan juga menjadikan perusahaan pelayaran lokal dapat bermain di wilayahnya sendiri dengan lebih maksimal [1].

\section{B. Pelabuhan Indonesia Timur}

Untuk menunjang program Tol Laut, pelabuhan-pelabuhan yang ada di Indonesia dibangun sesuai dengan fungsi dan kebutuhan pelabuhan dan pelayaran. Fasilitas-fasilitas dari pelabuhan tersebut sangat berpengaruh terhadap kapal-kapal yang bisa bersandar. Sudah terdapat enam pelabuhan yang direncanakan untuk pelabuhan-pelabuhan Tol Laut yang berada di wilayah Indonesia Timur yaitu pelabuhan Makassar, pelabuhan Bitung, pelabuhan Ternate, pelabuhan Ambon, pelabuhan Sorong, pelabuhan Jayapura [1].

\section{Kapal 3-in-1}

Kapal 3-in-1 merupakan sebuah inovasi khususnya di Indonesia yang dilakukan untuk memenuhi kebutuhan logistik. PT. Pelni sebagai salah satu perusahaan pelayaran di Indonesia sudah memiliki kapal 3-in-1 pengangkut penumpang, kontainer, dan barang dari hasil modifikasi kapal single purpose pengangkut penumpang. Modifikasi awalnya dilakukan pada salah satu kapal KM. Dobonsolo yang bisa mengangkut 300 unit kendaraan, 40 kontainer, dan 1200 orang penumpang [2].

\section{Sistem Modul Ruangan}

Modul ruangan seperti pada Gambar 1. adalah sistem yang membagi ruang besar menjadi beberapa bagian dengan ukuran yang standar dan disesuaikan [3].

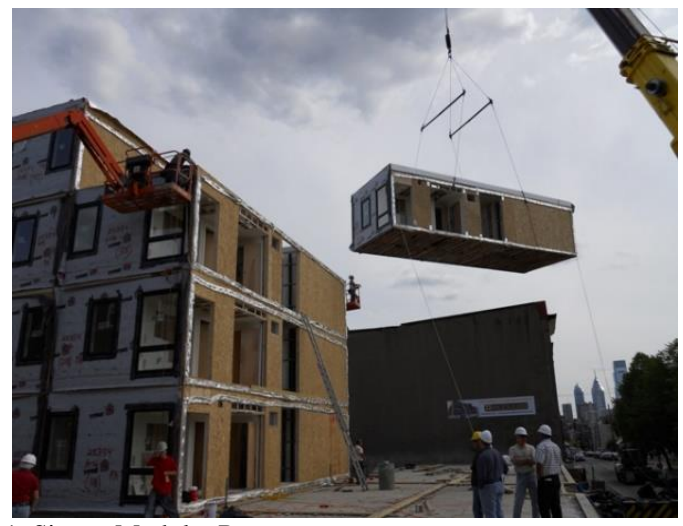

Gambar 1. Sistem Modular Ruangan.

Fungsi dari sitem modular dalam perencanaan dan pembangunan adalah memudahkan dan mempercepat dalam penataan dan proses pembangunan. Selain itu sistem modular dapat digunakan sebagai ruangan yang portable sehingga ruangan dapat menjadi fleksibel dan berfungsi sesuai dengan kebutuhan yang ada.

\section{METODOLOGI}

Penelitian ini diawali dengan identifikasi masalah yang ada dilanjutkan dengan pengumpulan data dan studi literatur. Dari data yang ada dilakukan analisis rute dan penentuan ukuran utama awal kapal. Ukuran utama awal dioptimasi menggunakan metode 256 dengan menganalisis teknis sehingga didapatkan ukuran utama akhir dengan displacement yang cukup dan BHP terendah. Tahap terakhir adalah menghasilkan rencana garis, rencana umum, model 3D, dan safety plan.

\section{ANALISIS TEKNIS}

\section{A. Analisis Rute}

Dari data pelabuhan yang ada, diambil rute dari jarak yang terdekat antar pelabuhan. Sehingga rute dari kapal 3-in-1 adalah pelabuhan Makassar (A) - Bitung (B) - Ternate (C) Ambon (D) - Sorong (E) - Jayapura (F) dan sebaliknya seperti pada Gambar 2.

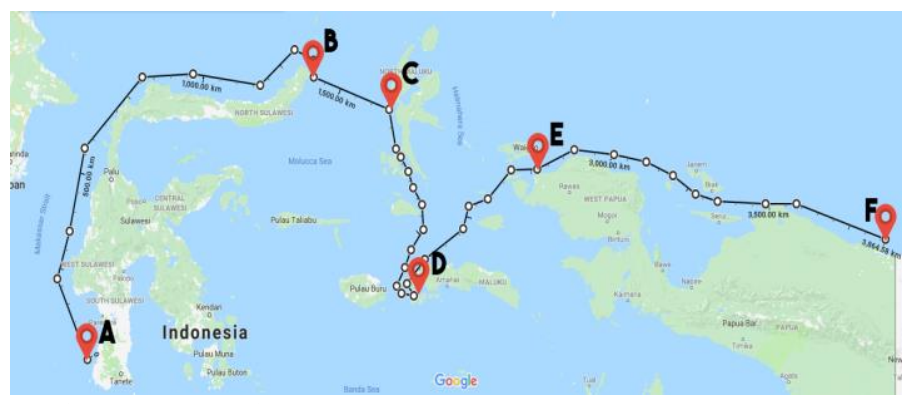

Gambar 2. Rute Kapal.

\section{B. Penentuan Muatan Kapal}

Muatan kapal ini dibagi menjadi dua yaitu saat modul bangunan atas terpasang dan modul bangunan atas dilepas. Muatan penumpang diambil dari data jumlah penumpang yang ada pada tiap pelabuhan, sementara kontainer dan kendaraan ditentukan dari kapal yang sudah ada KM. Dobonsolo. Berikut hasil analisis teknis penentuan muatan kapal 3-in-1 berupa jumlah penumpang, kendaraan, dan juga kontainer. Pada kondisi modul bangunan atas dipasang, muatan dapat dilihat pada Tabel 1.

Tabel 1.

Muatan Modul Bangunan Atas Terpasang

\begin{tabular}{ccc}
\hline \hline Muatan & Jumlah & Berat (ton) \\
\hline Penumpang & 1400 orang & 105 \\
Mobil L $<5 \mathrm{~m}$ & 40 unit & 200 \\
Truk $7 \mathrm{~m}<\mathrm{L}<10 \mathrm{~m}$ & 12 unit & 192 \\
Sepeda Motor & 322 unit & 96,6 \\
Kontainer & 41 TEUs & 1.230 \\
Berat total & & $1.823,6$ \\
\hline \hline
\end{tabular}

Untuk kondisi modul bangunan atas dilepas, muatan dapat dilihat pada Tabel 2.

Tabel 2.

Muatan Modul Bangunan Atas Dilepas

\begin{tabular}{ccc}
\hline \hline Muatan & Jumlah & Berat (ton) \\
\hline Penumpang & 400 orang & 30 \\
Mobil L $<5 \mathrm{~m}$ & 40 unit & 200 \\
Truk $7 \mathrm{~m}<\mathrm{L}<10 \mathrm{~m}$ & 12 unit & 192 \\
Sepeda Motor & 322 unit & 96,6 \\
Kontainer & 89 TEUs & 2.670 \\
Berat Total & & $3.188,6$ \\
\hline \hline
\end{tabular}




\section{C.Penentuan Ukuran Utama}

Selanjutnya adalah penentuan ukuran utama awal dengan menggunakan parent ship KM. Dobonsolo. Berikut nilai ukuran utama awal.

Tabel 3.

Ukuran Utama Awal

\begin{tabular}{ccc}
\hline \hline Ukuran Utama & Nilai & Satuan \\
\hline Lpp & 130 & meter \\
B & 23,4 & meter \\
H & 13,4 & meter \\
T & 5,9 & meter \\
\hline \hline
\end{tabular}

Ukuran utama awal tersebut dioptimasi 256 melalui kenaikan dan penurunan $\mathrm{Fn}, \mathrm{L} / \mathrm{B}, \mathrm{B} / \mathrm{T}$, dan T/H sebanyak 5\% dan 1,667\% [4]. Dari 256 pasang ukuran utama dicari ukuran yang displacementnya memenuhi, lebar kapal $>22,7 \mathrm{~m}$, dan memiliki BHP terkecil. Berikut nilai ukuran utama optimum.

Tabel 4.

Ukuran Utama Optimum

\begin{tabular}{ccc}
\hline \hline Ukuran Utama & Nilai & Satuan \\
\hline Lpp & 139,8 & meter \\
B & 24 & meter \\
H & 12,8 & meter \\
T & 5,95 & meter \\
\hline \hline
\end{tabular}

\section{D.Hambatan dan Propulsi Kapal}

Dari ukuran utama akhir dihitung koefisien bentuk badan kapal dan dilanjutkan dengan menghitung hambatan, propulsi kapal sehingga kapasitas mesin induk dapat ditentukan.

Tabel 5.

Koefisien Bentuk Badan Kapal dan Kebutuhan Propulsi Kapal

\begin{tabular}{lll}
\hline \hline & Nilai & Keterangan \\
\hline $\mathrm{C}_{\mathrm{B}}$ & 0,664 & \\
$\mathrm{C}_{\mathrm{P}}$ & 0,676 & \\
$\mathrm{C}_{\mathrm{M}}$ & 0,982 & \\
$\mathrm{C}_{\mathrm{WP}}$ & 0,761 & \\
$\mathrm{LCB}$ & 64,457 & meter dari AP \\
Displ (volume) & $13.785,953$ & $\mathrm{~m}^{3}$ \\
Displ (mass) & $14.130,602$ & $\mathrm{ton}$ \\
$\mathrm{RT}_{\mathrm{BHP}}$ MCR & $13.412,238$ & $\mathrm{kN}$ \\
Daya Mesin & $4.296,890$ & $\mathrm{~kW} / \mathrm{mesin}$ \\
Daya Genset & 2.500 & $\mathrm{~kW} / \mathrm{mesin}$ \\
\hline \hline
\end{tabular}

\section{E. Berat dan Titik Berat Kapal}

Dalam analisis teknis, dihitung DWT dan LWT beserta titik berat dari komponen dari tiap-tiap kondisi modul bangunan atas. Berikut hasil dari perhitungan DWT dan LWT beserta titk berat dari masing-masing komponen.

Tabel 6.

Berat Kapal saat Modul Bangunan Atas Terpasang

\begin{tabular}{lll}
\hline Komponen & Nilai & Keterangan \\
\hline DWT & $2.974,009$ & ton \\
LWT & $9.940,852$ & ton \\
Koreksi & $8.603 \%$ & Max 10\% (Acc) \\
LCG Total & 63,516 & m dari AP \\
VCG Total & 5,929 & m dari AP \\
\hline \hline
\end{tabular}

Tabel 7.

Berat Kapal saat Modul Bangunan Atas Dilepas

\begin{tabular}{lll}
\hline \hline Komponen & Nilai & Keterangan \\
\hline DWT & $3.629,008$ & ton \\
LWT & $9.457,193$ & ton \\
Koreksi & $7.391 \%$ & Max 10\% (Acc) \\
LCG Total & 63,516 & m dari AP \\
VCG Total & 4,975 & m dari AP \\
\hline \hline
\end{tabular}

\section{F. Freeboard}

Kapal 3-in-1 ini merupakan kapal tipe B sehingga perhitungan lambung timbul menggunakan tabel kapal tipe B. Nilai lambung timbul yang didesain harus berinilai lebih besar atau sama dengan dari nilai lambung timbul standar. Berikut hasil perhitungan lambung timbul yang telah dilakukan.

Tabel 8.

Perhitungan Freeboard

\begin{tabular}{lll}
\hline \hline & Nilai & Keterangan \\
\hline Lambung timbul standar & 1.640 & $\mathrm{~mm}$ \\
Lambung timbul desain & 6.850 & $\mathrm{~mm}$ \\
Status & Nilai desain > nilai standar & Accepted \\
\hline \hline
\end{tabular}

\section{G. Trim dan Stabilitas}

Dalam analisis stabilitas dan trim, terdapat 16 kondisis dari tiap-tiap kondisi modul bangunan atas, sehingga total terdapat 32 load case (LC). Untuk analisis trim dilakukan dengan nilai maksimal trim yang diijinkan adalah $\pm 0.5 \%$ LWL atau \pm 0,727 meter. Dari analisis awal, terdapat beberapa loadcase yang tidak memenuhi sehingga perlu ditambahkan ballast di beberapa tangki. Sehingga hasil akhir trim dapat dilihat pada Tabel 9 dan Tabel 10.

Tabel 9.

\begin{tabular}{ccc} 
Trim saat Modul Bangunan Atas Dipasang \\
\hline \hline & Nilai Ta-Tf & Keterangan \\
\hline LC1 & 0,280 & Accepted \\
LC2 & 0,351 & Accepted \\
LC3 & 0,397 & Accepted \\
LC4 & 0,103 & Accepted \\
LC5 & $-0,591$ & Accepted \\
LC6 & $-0,128$ & Accepted \\
LC7 & $-0,486$ & Accepted \\
LC8 & $-0,036$ & Accepted \\
LC9 & 0,287 & Accepted \\
LC10 & 0,000 & Accepted \\
LC11 & 0,392 & Accepted \\
LC12 & 0,102 & Accepted \\
LC13 & $-0,600$ & Accepted \\
LC14 & $-0,142$ & Accepted \\
LC15 & $-0,496$ & Accepted \\
LC16 & $-0,052$ & Accepted \\
\hline \hline
\end{tabular}

Tabel 10.

Trim saat Modul Bangunan Atas Dilepas

\begin{tabular}{ccc}
\hline \hline & Nilai Ta-Tf & Keterangan \\
\hline LC1 & 0,056 & Accepted \\
LC2 & 0,456 & Accepted \\
LC3 & 0,061 & Accepted \\
LC4 & 0,566 & Accepted \\
LC5 & 0,655 & Accepted \\
LC6 & 0,363 & Accepted \\
LC7 & $-0,017$ & Accepted \\
LC8 & 0,455 & Accepted \\
LC9 & $-0,091$ & Accepted \\
LC10 & 0,420 & Accepted \\
LC11 & 0,025 & Accepted \\
LC12 & 0,528 & Accepted \\
LC13 & 0,616 & Accepted \\
LC14 & 0,320 & Accepted \\
LC15 & 0,717 & Accepted \\
LC16 & 0,421 & Accepted \\
\hline \hline
\end{tabular}

Setelah analisis trim, semua kondisi yang telah memenuhi aturan trim diperiksa. Kriteria Stabilitas dapat dilihat pada Tabel 11. 
Tabel 11.

Kriteria Stabilitas

\begin{tabular}{cc}
\hline \multicolumn{2}{c}{ Kriteria } \\
\hline Area 0 to 30 & $\geq 3.151 \mathrm{~m} . \mathrm{rad}$ \\
Area 0 to 40 & $\geq 5.157 \mathrm{~m} \cdot \mathrm{rad}$ \\
Area 30 to 40 & $\geq 1.719 \mathrm{~m} \cdot \mathrm{rad}$ \\
Max GZ at 30 or Greater & $\geq 0.200 \mathrm{~m}$ \\
Angle of Maximum GZ & $\geq 25.000 \mathrm{~m}$ \\
Initial GMt & $\geq 0.150 \mathrm{~m}$ \\
Passenger Crowding & $\leq 10 \mathrm{deg}$ \\
Angle of Equilibrium & $\leq 10 \mathrm{deg}$ \\
\hline \hline
\end{tabular}

Setelah dilakukan analisis, stabilitas dari bangunan atas terpasang dan Dilepas dapat dilihat pada Tabel 12 dan Tabel 13. Pada tiap kondisi modul bangunan atas, kapal 3-in-1 ini sudah memenuhi kriteria stabilitas.

Tabel 12.

Stabilitas saat Modul Bangunan Atas Terpasang

\begin{tabular}{|c|c|c|c|c|c|c|c|c|}
\hline \multirow{2}{*}{$\begin{array}{c}\text { Load } \\
\text { Case }\end{array}$} & $\begin{array}{c}\text { Area 0 } \\
\text { to } 30\end{array}$ & $\begin{array}{c}\text { Area 0 } \\
\text { to } 40\end{array}$ & $\begin{array}{c}\text { Area } \\
30 \\
40\end{array}$ & $\begin{array}{c}\text { Max GZ at } \\
30 \text { or } \\
\text { Greater }\end{array}$ & $\begin{array}{c}\text { Angle of } \\
\text { Maximu } \\
m \text { GZ }\end{array}$ & $\begin{array}{c}\text { Initial } \\
\text { GMt }\end{array}$ & $\begin{array}{c}\text { Passenger } \\
\text { Crowding }\end{array}$ & $\begin{array}{c}\text { Angle of } \\
\text { Equilitibrium }\end{array}$ \\
\cline { 2 - 9 } & Actual & Actual & Actual & Actual & Actual & Actual & Actual & Actual \\
\hline 1 & 34.434 & 60.985 & 26.551 & 3.874 & 45.500 & 3.800 & 1.500 & 0.000 \\
\hline 2 & 24.792 & 43.443 & 18.650 & 1.929 & 40.000 & 2.551 & 2.400 & 0.000 \\
\hline 3 & 35.364 & 62.427 & 27.064 & 2.930 & 45.500 & 3.921 & 1.500 & 0.000 \\
\hline 4 & 26.833 & 47.518 & 20.685 & 2.166 & 40.900 & 2.796 & 2.100 & 0.000 \\
\hline 5 & 35.150 & 61.058 & 25.908 & 2.743 & 42.700 & 3.912 & 1.700 & 0.000 \\
\hline 6 & 28.745 & 50.364 & 21.619 & 2.265 & 40.900 & 3.062 & 2.000 & 0.000 \\
\hline 7 & 37.518 & 65.910 & 28.392 & 3.066 & 45.500 & 4.194 & 1.500 & 0.000 \\
\hline 8 & 27.444 & 47.407 & 19.964 & 2.057 & 39.100 & 2.918 & 2.400 & 0.000 \\
\hline 9 & 35.425 & 62.601 & 27.176 & 2.946 & 45.500 & 3.924 & 1.500 & 0.000 \\
\hline 10 & 26.941 & 47.773 & 20.832 & 2.183 & 40.900 & 2.808 & 2.100 & 0.000 \\
\hline 11 & 36.391 & 64.095 & 27.704 & 3.003 & 45.500 & 4.049 & 1.500 & 0.000 \\
\hline 12 & 27.748 & 48.985 & 21.237 & 2.225 & 40.900 & 2.916 & 2.100 & 0.000 \\
\hline 13 & 37.579 & 66.087 & 20.508 & 3.082 & 45.500 & 4.200 & 1.500 & 0.000 \\
\hline 14 & 27.691 & 47.691 & 20.139 & 2.078 & 39.100 & 2.930 & 2.400 & 0.000 \\
\hline 15 & 38.643 & 67.710 & 29.068 & 3.142 & 45.500 & 4.349 & 1.500 & 0.000 \\
\hline 16 & 28.510 & 49.048 & 20.537 & 2.117 & 39.100 & 3.070 & 2.300 & 0.000 \\
\hline
\end{tabular}

Tabel 13

Stabilitas saat Modul Bangunan Atas Dilepas

\begin{tabular}{|c|c|c|c|c|c|c|c|c|}
\hline \multirow{2}{*}{$\begin{array}{c}\text { Load } \\
\text { Case }\end{array}$} & $\begin{array}{c}\text { Area 0 } \\
\text { to } 30\end{array}$ & $\begin{array}{c}\text { Area 0 } \\
\text { to } 40\end{array}$ & $\begin{array}{c}\text { Area } \\
30 \\
40\end{array}$ & $\begin{array}{c}\text { Max GZ at } \\
\begin{array}{c}30 \text { or } \\
\text { Greater }\end{array}\end{array}$ & $\begin{array}{c}\text { Angle of } \\
\text { Maximum } \\
\text { GZ }\end{array}$ & $\begin{array}{c}\text { Initial } \\
\text { GMt }\end{array}$ & $\begin{array}{c}\text { Passenger } \\
\text { Crowding }\end{array}$ & $\begin{array}{c}\text { Angle of } \\
\text { Equilibrium }\end{array}$ \\
\hline & Actual & Actual & Actual & Actual & Actual & Actual & Actual & Actual \\
\hline 1 & 31.774 & 56.763 & 24.988 & 2.702 & 44.500 & 3.467 & 0.400 & 0.000 \\
\hline 2 & 22.388 & 39.844 & 45.660 & 1.808 & 39.100 & 2.239 & 0.700 & 0.000 \\
\hline 3 & 32.579 & 58.039 & 25.459 & 2.753 & 44.500 & 3.566 & 0.400 & 0.000 \\
\hline 4 & 23.101 & 40.899 & 17.799 & 1.842 & 39.100 & 2.329 & 0.400 & 0.000 \\
\hline 5 & 40.684 & 71.285 & 30.601 & 3.355 & 47.300 & 4.616 & 0.400 & 0.000 \\
\hline 6 & 30.954 & 53.380 & 22.425 & 2.338 & 40.900 & 3.370 & 0.500 & 0.000 \\
\hline 7 & 45.423 & 80.927 & 35.504 & 4.143 & 54.500 & 5.471 & 0.200 & 0.000 \\
\hline 8 & 37.540 & 66.834 & 29.294 & 3.262 & 48.200 & 4.409 & 0.300 & 0.000 \\
\hline 9 & 37.341 & 66.989 & 29.648 & 3.419 & 52.700 & 4.558 & 0.300 & 0.000 \\
\hline 10 & 29.719 & 53.663 & 23.945 & 2.627 & 45.500 & 3.509 & 0.400 & 0.000 \\
\hline 11 & 38.042 & 68.226 & 30.184 & 3.478 & 52.700 & 4.617 & 0.300 & 0.000 \\
\hline 12 & 30.353 & 54.740 & 24.386 & 2.675 & 46.400 & 3.563 & 0.400 & 0.000 \\
\hline 13 & 44.738 & 79.792 & 35.053 & 4.090 & 54.400 & 5.382 & 0.300 & 0.000 \\
\hline 14 & 36.893 & 65.800 & 28.907 & 3.219 & 48.200 & 4.329 & 0.300 & 0.000 \\
\hline 15 & 45.656 & 81.325 & 35.669 & 4.164 & 54.400 & 5.483 & 0.200 & 0.000 \\
\hline 16 & 37.760 & 67.201 & 29.442 & 3.280 & 48.200 & 4.421 & 0.300 & 0.000 \\
\hline
\end{tabular}

\section{H. Cargo Securing}

Penjagaan cargo dibagi menjadi dua yaitu penjagaan untuk kontainer dan kendaraan. Penjagaan kontainer meliputi penjagaan untuk kontainer muatan (cargo container) dan kontainer ruangan (accommodation modules).

\section{Cargo Container}

Penjagaan kontainer muatan menggunakan Lashing Rod,

Twist Lock, dan Turnbuckle [5].

2. Accomodation Modules

Penjagaan modul bangunan atas menggunakan, Lashing

Rod, Twist Lock, Turnbuckle, dan Bridge Lock [5].

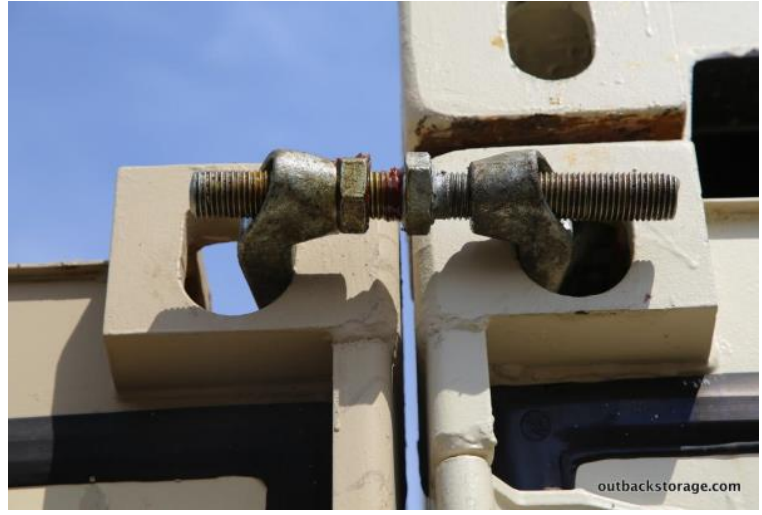

Gambar 3. Container Bridge Fitter.

Untuk penjagaan kendaraan meliputi mobil $(\mathrm{L}<5 \mathrm{~m})$, truk

$(7 \mathrm{~m}<\mathrm{L}<10 \mathrm{~m})$ dan motor.

1. Mobil $(\mathrm{L}<5 \mathrm{~m})$

Penjagaan mobil direncakanan menggunakan $D$ Rings dan Straps.

2. Truk $(7 \mathrm{~m}<\mathrm{L}<10 \mathrm{~m})$

Penjagaan truk direncakanan menggunakan $D$ ring, Chain with Hook, dan Truck Speed Lash.

3. Motor

Penjagaan motor direncakanan menggunakan $D$ Rings dan Straps.

\section{LAMPIRAN}

\section{A. Desain 3D Kapal}

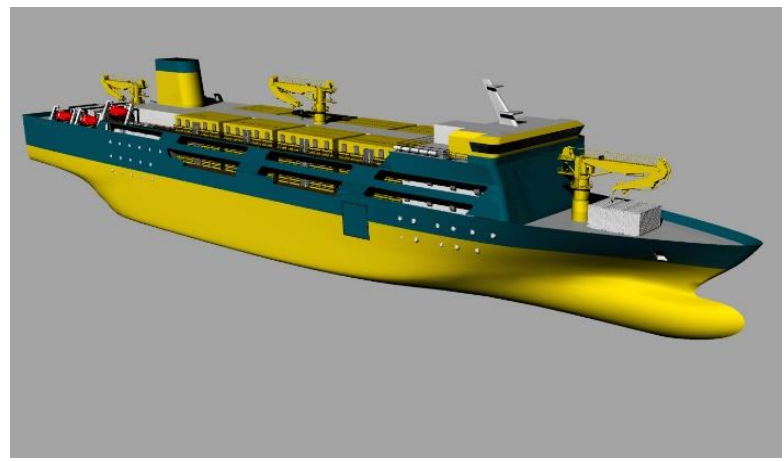

Gambar 4. Model 3D Kapal Bangunan Atas Terpasang

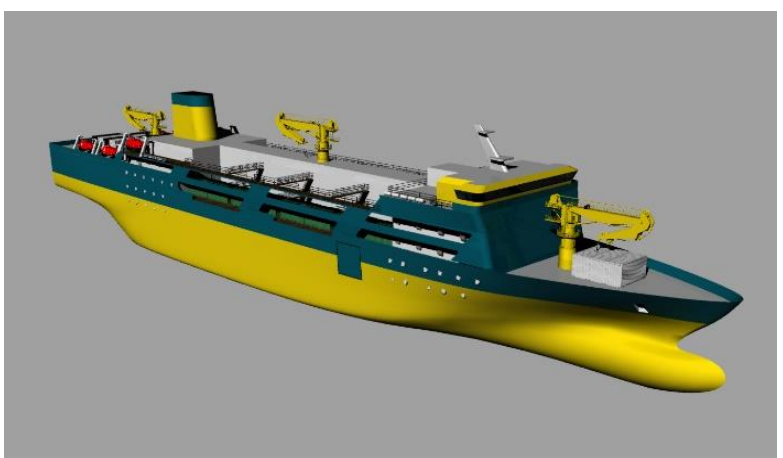

Gambar 5. Model 3D Kapal Bangunan Atas Dilepas 


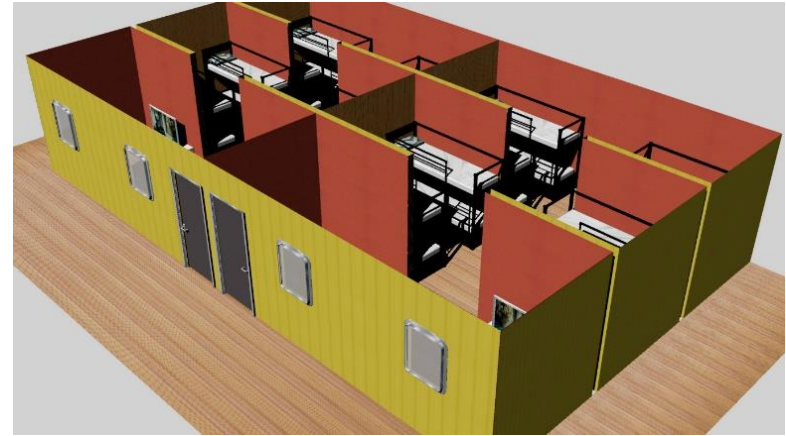

Gambar 6. Kamar Kelas II (Portable Module)

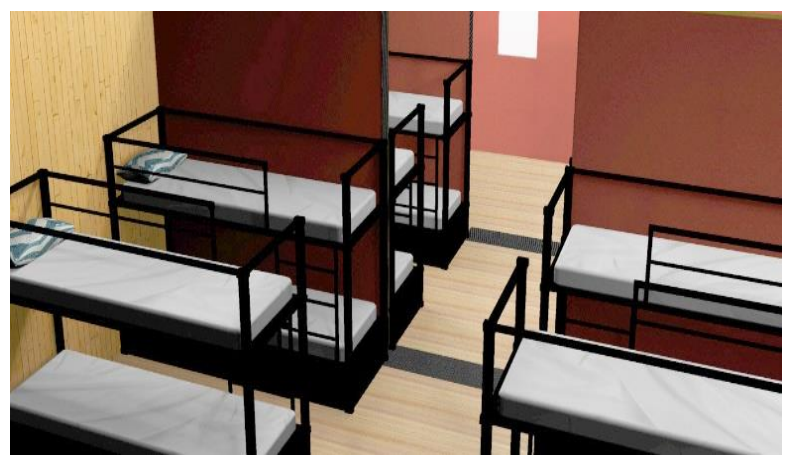

Gambar 7. Interior Kamar Kelas II (Portable Module).

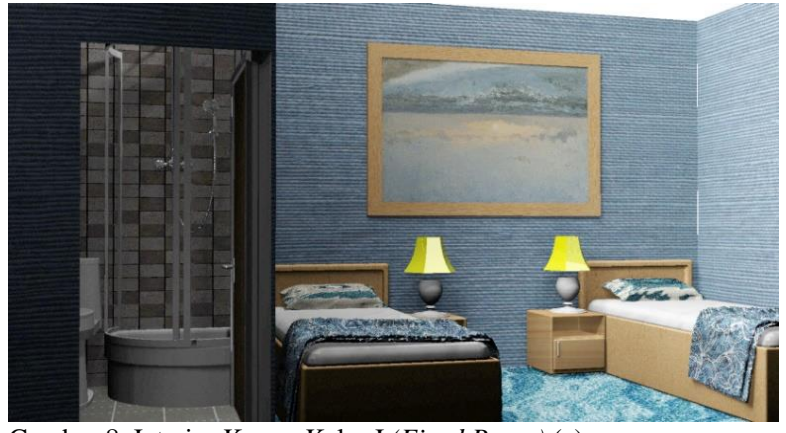

Gambar 8. Interior Kamar Kelas I (Fixed Room) (a).

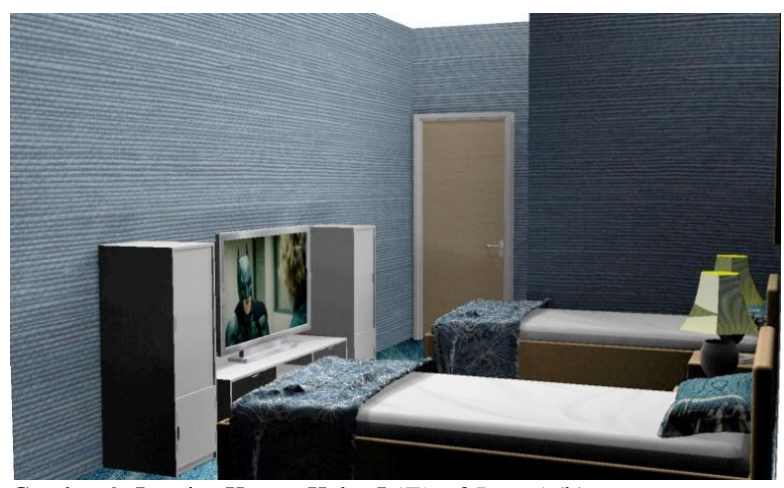

Gambar 9. Interior Kamar Kelas I (Fixed Room) (b).

\section{B. Rencana Garis}
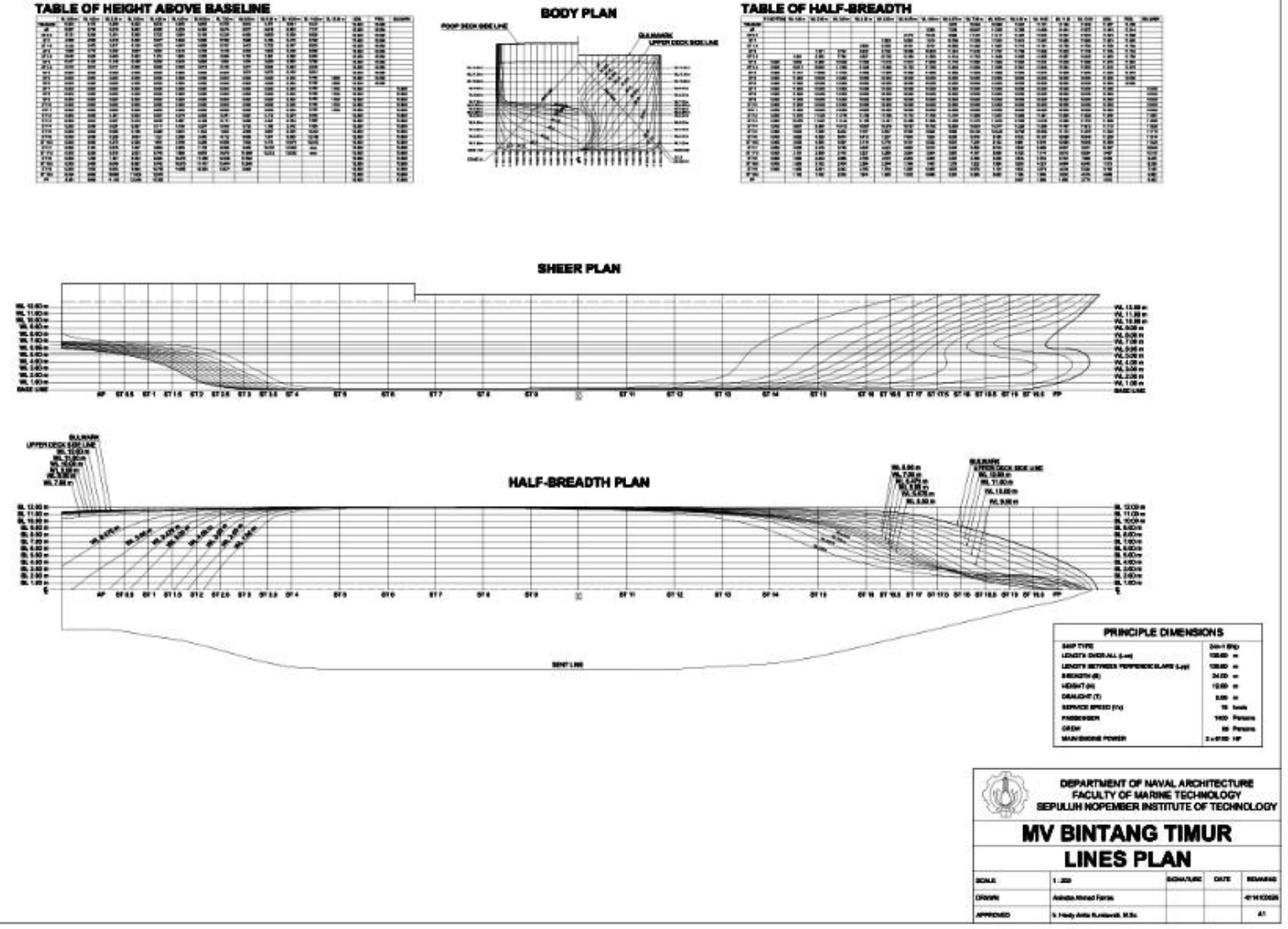


\section{Rencana Umum}

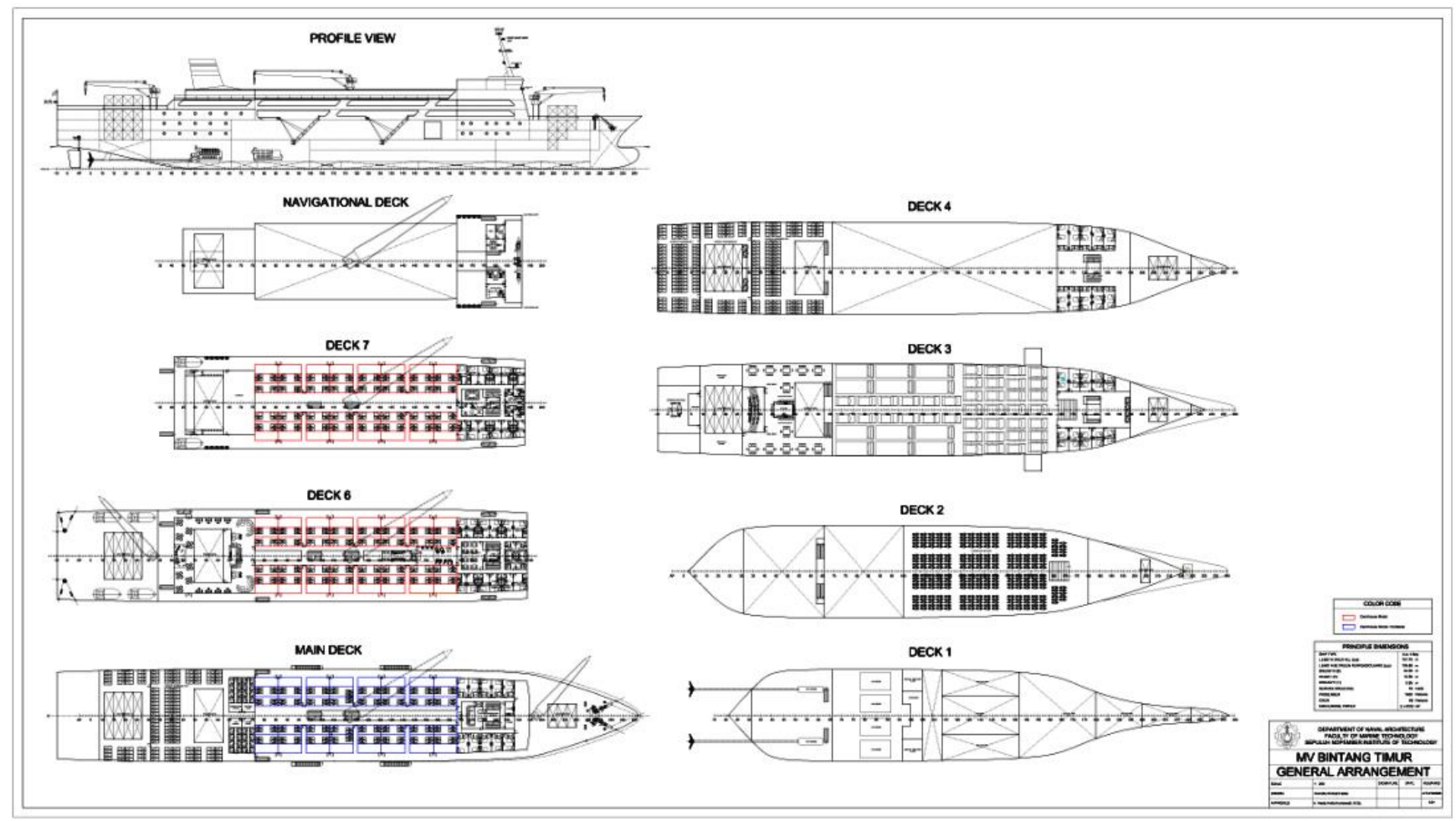

Gambar 11. Rencana Umum.

\section{KESIMPULAN}

Telah didesain kapal 3-in-1 multipurpose dengan bangunan atas portable dengan spesifikasi teknis sebagai berikut:

1. Rute pelayaran Makassar - Bitung - Ternate - Ambon Sorong - Jayapura dan sebaliknya.

2. Ukuran utama kapal sebagai berikut:

- Length of perpendicular (Lpp) : 139,8 meter

- Breadth (B)

- Height $(\mathrm{H})$

- Draft (T)

3. Memenuhi aturan stabilitas, titik berat, trim, dan freeboard.

\section{: 24 meter \\ : 12.8 meter : 5.95 meter}

\section{DAFTAR PUSTAKA}

[1] B. Prihartono, Pengembangan Tol Laut Dalam RPJMN 2015-2019 dan Implementasi 2015. Jakarta: Kementrian Perencanaan Pembangunan Nasional, 2015.

[2] PT. Pelayaran Nasional Indonesia, Camar Caraka Maritim, 19th ed. Jakarta: PT. Pelayaran Nasional Indonesia, 2013.

[3] Inhabitat, "The Modules: LEED Silver Modular Housing At Temple University," 2010. [Online]. Available: https://inhabitat.com/themodules-leed-silver-modular-housing-at-temple-university.

[4] J. Tupan, "Analisis Teknis dan Ekonomis Pengadaan Kapal Barang untuk Kapet Seram," Surabaya, 2005.

[5] Outback Storage, "Bridge Fitting," 2017. 